[Agr. Biol. Chem., Vol. 30, No. 10, p. 994 1003, 1966]

\title{
Reversibility of Heat-Inactivation of Bacillus subtilis' $\alpha$-Amylase
}

\author{
By Takehiko Yамamoto, Akimasa Nishida and Juichiro Fukumoto \\ Faculty of Science, Osaka City University \\ Received April 2, 1966
}

\begin{abstract}
Inactivation of Bacillus subtilis' $\alpha$-amylase by heat was found to be reversible under a certain condition, and the factors affecting there were investigated, distinguishing into two groups: those influencing on the inactivation process by heat and those on the reactivation at the subsequent incubation' after heating. Generally, the amylase heated in borate buffer solution was best in the reactivation degree.' For reactivation of the heat-inactivated enzyme there was found an optimum in temperature, $\mathrm{pH}$ and concentration of enzyme, respectively. The reactivation was temporarily prevented by urea, but irreversibly inhibited by either calcium salts or calcium binding agents. In the reversible heat-inactivation of the enzyme was also found a reversible change in the absorption spectra as well as in the behavior of the enzyme toward proteinase.
\end{abstract}

Many experimental results have indicated that denatured enzyme is renatured under a certain condition. The study of reversible denaturation of enzyme protein is of importance to approach the study on the relationship between the conformational structure of enzyme protein and enzyme activity.

As for reversible denaturation of enzyme by heat, there have been several papers such as on Taka-amylase, ${ }^{1)}$ Trypsin, ${ }^{2}$ Proteus vulgaris' nucleotide pyrophosphatase, ${ }^{3 \prime}$ etc. Our previous paper ${ }^{4}$ has reported that Bac. subtilis' $\alpha$ amylase inactivated by heat restores its activity under a certain condition. Recently, it was found that the reactivation of heat-inactivated amylase was reversibly inhibited by urea.

It is well-known that Bac. subtilis' $\alpha$-amylase contains neither cysteine nor cystine and that the enzyme possesses one gram atom of calcium as an indispensable constituent for enzyme activity. The enzyme thus loses its

1) E. Ohlsons and T. Sweitchin, Bull. Soc. Chem. Biol., 11, 333 (1929); 15, 470 (1933).

2) M.L. Anson and A.E. Mirsky, J. Gen. Physiol., 17, 393 (1934).

3) M. N. Swartz, N. O. Kaplan and M. F. Lanborg, J. Biol. Chem., 232, 1051 (1958).

4) T. Yamamoto, A. Nishida and J. Fukumoto, This Journal, 28, 656 (1964). activity when made free from the calcium and the inactivated amylase is reactivated upon addition of calcium ions. ${ }^{5 \sim 7)}$ This fact clearly indicates that the active structure of the enzyme is achieved by chelating in a certain way with calcium. Thus, there may be the possibility that the metal in the enzyme protein also plays an important role for reactivation of the heat-inactivated amylase.

The present paper deals with the condition of reversible heat-inactivation of Bac: subtilis? $\alpha$-amylase and some properties of the amylase reversibly inactivated by heat.

\section{MATERIALS AND METHODS}

Amylase. The crystalline Bac. subtilis' $\alpha$-amylase used in the present work was obtained according to the method reported by one of the present authors. In order to remove contaminated protease, the crystalline amylase was dissolved in a dilute sodium hydroxide solution and dialyzed against a slightly alkaline solution ( $\mathrm{pH}$ 8.4) for four days in the cold. The dialyzed amylase was then heated at $70^{\circ} \mathrm{C}$ for $30 \mathrm{~min}$. and, after cooling by allowing to stand at

5) E.H. Fischer et al., The 4th International Congress of Biochemistry, Symposium 8 3, 1958.

6) T. Yamamoto, This Journal, 23, 68 (1959)

7) T. Yamamoto, ibid., 24, 16 (1960).

8) T. Yamamoto, ibid., 19, 121 (1955). 
room temperature for several hours, was dialyzed against deionized water for two days in the cold. The dialyzed amylase was centrifuged if any precipitate occurred and calcium acetate solution was added in a minimum amount sufficient to crystallize out the enzyme. The crystals thus obtained were again dissolved in a slightly alkaline solution and dialyzed against deionized water for several days to remove excessive calcium. The dialyzed enzyme was then freeze-dried; the preparation was very soluble in deionized water (ca. $30 \%$ by weight) and one per cent solution of the enzyme gave a value of 25.0 at $280 \mathrm{~m} \mu$ per $\mathrm{cm}$. The activity of the enzyme preparation was $\$ 80$ units per $\mathrm{mg}$ when determined by the following issay method.

Enzyme activity assay. To $4 \mathrm{ml}$ of a $0.5 \%$ ioluble starch solution buffered with $\mathrm{M} / 50$ acetic acidimmonium acetate at $\mathrm{pH} 5.9$ was added one $\mathrm{ml}$ of :nzyme and incubated at $40^{\circ} \mathrm{C}$. After $3 \mathrm{~min}$., the educing sugar formed was determined by the Shafferjomogyi's method. ${ }^{9)}$ One unit of enzyme activity vas defined as the enzyme quantity that produced one $x$ mole of reducing sugar as glucose per min. under he condition.

Difference spectra. Difference spectra were measured in matched quartz cells of one $\mathrm{cm}$ path on the to Chotampa QU-2 model spectrophotometer. In he spectroscopy, solutions containing about $0.5 \mathrm{mg}$ if $\alpha$-amylase per $\mathrm{ml}$ in $\mathrm{M} / 400$ borate buffer at $\mathrm{pH}$ 1.6 were used and the absorbancy of heated amylase olution was measured against unheated amylase as be control. Because of considerably rapid change b absorbancy of amylase during heating, the absorpion was followed as a function of time measuring $t$ given wavelengths, and the difference spectra were btained from the results. The change in absorbancy ith change in temperature was also determined quipping a special thermostat for cuvette, the temerature of which was raised at a constant rate by se aid of the Haake circulating thermostat.

Fractional determination of native and denatura amylase. The well-known fact, that, under a cerin condition, native enzyme is quite resistant to proolytic enzyme while denatured enzyme is extremely nsitive, was applied here. At varied times of incuItion of amylase after heating, $0.5 \mathrm{ml}$ of $\mathrm{Bac}$. sublis' alkaline protease (Nagarse, $0.12 \mathrm{mg} / \mathrm{ml}$ of $\mathbf{M} / 10$ lospate, $\mathrm{pH} 7.0$ ) was mixed with $3 \mathrm{ml}$ of amylase

9) P.A. Shaffer and M. Somogyi, J. Biol. Chem., 100, 695 B33). and, after a given time at $30^{\circ} \mathrm{C}, 3.5 \mathrm{ml}$ of TCA mixture $(0.33 \mathrm{~N}$ trichloroacetic acid, $0.66 \mathrm{~N}$ acetic acid, $0.99 \mathrm{~N}$ sodium acetate) was added. The filtrate of the mixture obtained after $30 \mathrm{~min}$. was subjected to colorimetric determination according to the modified Folin-Ciocalteau's method.10)

\section{EXPERIMENTAL RESULTS}

\section{Inactivation and Reactivation of Amylase}

There were found various factors which affected on reversible inactivation of $\mathrm{Bac}$. subtilis' $\alpha$-amylase by heat. They were clearly distinguished into two groups, one those affecting at heating and the other those affecting after heating.

\section{A. Factors affecting at heating}

1) pH, sort of buffer solutions or salts. The freeze-dried amylase was dissolved in $\mathrm{m} / 60$ buffer solution of borate, tris (trihydroxymethyl-aminomethane), phosphate or acetate of various $\mathrm{pH}$ values and, after heating at $80^{\circ} \mathrm{C}$ for $10 \mathrm{~min}$. and subsequently cooling at $24^{\circ} \mathrm{C}$, the enzyme activity was assayed at varied times of incubation at $24^{\circ} \mathrm{C}$. The borate buffer used here was prepared without any addition of $\mathrm{NaCl}$. As shown in Fig. 1, the best recovery of enzyme activity was found with amylase heated in $\mathrm{m} / 60$ borate buffer solution. On the other hand, the amylase in acetic acid- sodium acetate solution lost its activity by heating without showing any activity recovery. In solutions containing $\mathrm{Ca}^{++}, \mathrm{Na}^{+}$and $\mathrm{Cl}^{-}$which are known to increase the thermal stability of amylase, the loss of amylase activity was small, but no increase in enzyme activity was found during subsequent incubation after heating. However, the amylase dissolved in acetate buffer of concentrations less than $\mathrm{m} / 120$ showed an appreciable recovery of amylase activity (Fig. 2). The amylase solution slightly alkalized with $\mathrm{NaOH}$ ( $\mathrm{pH} 8.4$ ) also showed reactivation. However, the amylase which was dissolved only in deionized water ( $\mathrm{pH} 5.2$ ), $\mathrm{m} / 400$ Ca-acetate or solutions of various inorganic

10) O. Folin and V. Ciocalteau, J. Biol. Chem., 73, 627 (1927). 

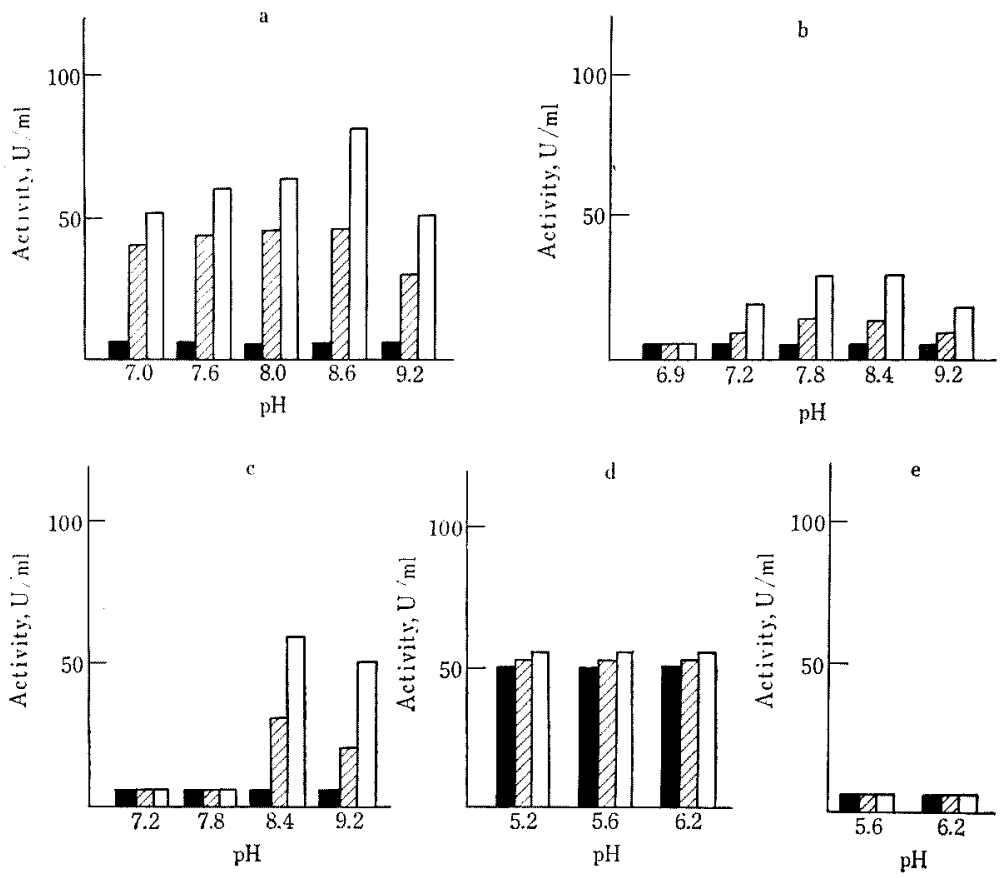

FIG. 1. Effect of $\mathrm{pH}$ and Various Buffer Solutions on Reversible Heat-Inactivation of Amylase.

, immediately after heating; IIIIII, after $30 \mathrm{~min}$; $\square$, after $150 \mathrm{~min}$. a, $M / 60$ borate buffer; $\quad b, M / 60$ phosphate buffer; $\quad c, M / 60$ tris buffer; d, $\mathrm{M} / 100 \mathrm{Ca}$-acetete $+\mathrm{M} / 20 \mathrm{NaCl}$; e, $\mathrm{M} / 90$ acetic-Na-acetate.
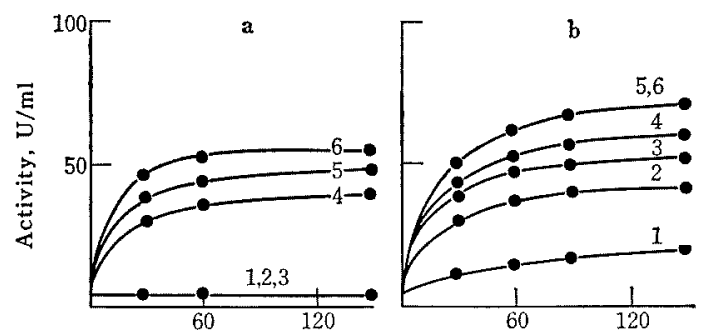

FIG. 2. Effect of Concentration of Buffer.

The amylase dissolved in the buffer solutions indicated was heated at $85^{\circ} \mathrm{C}$ for $10 \mathrm{~min}$. and then incubated at $30^{\circ} \mathrm{C}$.

a, acetic-sodium acetate $(\mathrm{pH} 5.95 \sim 6.05)$;

b, borate $\quad(\mathrm{pH} 8.2 \sim 8.4)$

$1, \mathrm{M} / 15 ; 2, \mathrm{M} / 30 ; 3, \mathrm{M} / 60 ; 4, \mathrm{M} / 120 ; 5, \mathrm{M} / 240 ; 6, \mathrm{M} / 480$.

salts of concentrations more than $\mathrm{m} / 400$ resulted in complete loss of enzyme activity and no reactivation was found.

2) Temperature. The recovery of amylase activity after heating was found to differ

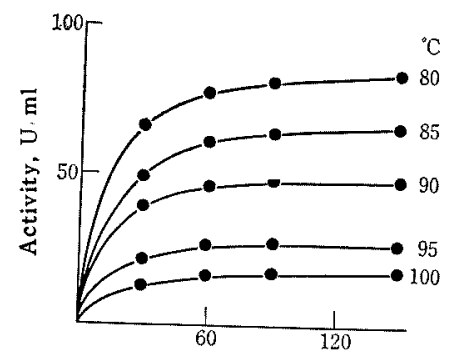

Time, min.

FIG. 3. Temperature of Heating and Reversibility of Amylase.

The amylase dissolved in a borate buffer of $\mathrm{M} / 240, \mathrm{pH}$ 8.6 , was heated for $10 \mathrm{~min}$. at the temperatures indicated and subsequently incubated at $30^{\circ} \mathrm{C}$.

according to the temperature to which the enzyme was exposed. As shown in Fig. 3, the activity recovery was best with the enzyme heated at $80^{\circ} \mathrm{C}$ and the higher the temperature, 
the less recovery of enzyme activity was obtained. However, it was worthy to note that even the amylase heated at $100^{\circ} \mathrm{G}$ for $10 \mathrm{~min}$. clearly showed restoration of activity up to a $15 \%$ of the original.

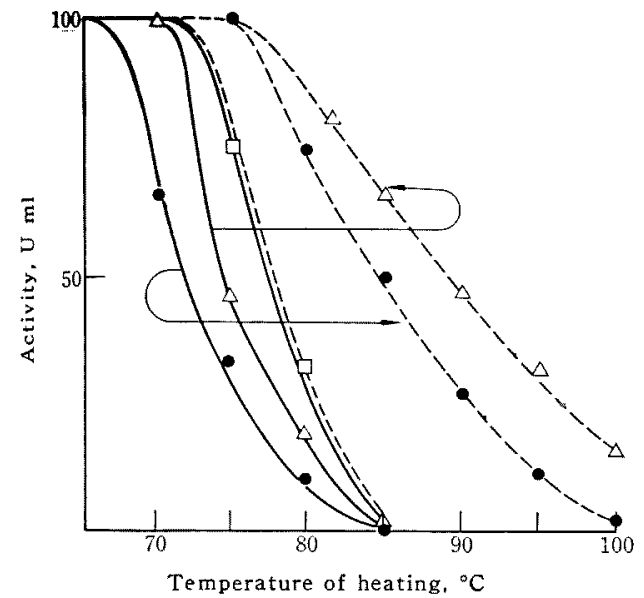

FIG. 4. Restoration, of Activity after Heating at Various Temperatures for $10 \mathrm{~min}$.

The solid lines and the broken lines indicate the amylase activity determined right after heating and after incubation of the heated amylase for $150 \mathrm{~min}$. at $25^{\circ}$, respec tively.

$-1, \mathrm{M} / 400$ acetate buffer $(\mathrm{pH} 6.0)$ :

$-\Delta-, M / 400$ borate buffer $(\mathrm{pH} 8.6)$;

$-\square-, M / 400$ Ca-acetate (pH 6.0).

In Fig. 4 are shown the activities of amylase immediately after heating at various temperatures for $10 \mathrm{~min}$. and those after leaving the heated amylases at $25^{\circ} \mathrm{C}$ for $150 \mathrm{~min}$. The results indicate that, in solutions of borate buffer of $\mathrm{m} / 400(\mathrm{pH} 8.6)$ or of acetic-sodium acetate buffer of $\mathrm{m} / 400(\mathrm{pH} 6.0)$, the best reactivation of enzyme occurs on heating at temperatures between $80^{\circ}$ and $85^{\circ} \mathrm{C}$. Fig. 4 again indicates that the thermal stability of amylase is clearly increased by the presence of calcium acetate, but no reactivation is found with the enzyme heated with calcium ions.

3) Period of heating. The reversibility of heat-inactivation of amylase was also found to be affected by the period of heating, even at a given temperature. As shown in Fig. 5, the longer the period of heating, the less re-

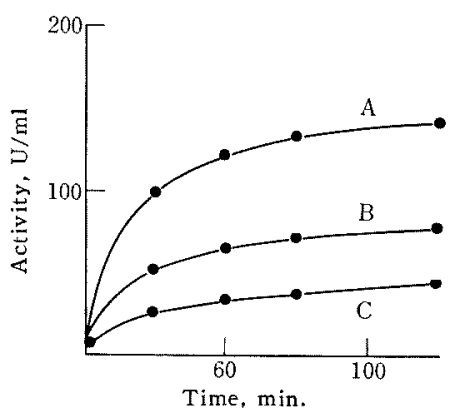

FIG. 5. Effect of Heating Period on the Reversibility.

The amylase dissolved in $\mathrm{M} / 400$ borate buffer, $\mathrm{pH} 8.4$, was heated at $85^{\circ} \mathrm{C}$ for the period indicated and then incubated at $30^{\circ} \mathrm{C}$.

A, 10 min.; B, 20 min.; $\quad$ C, 30 min.

activation was obtained.

4) Concentration of enzyme. The concentration of enzyme is an important factor affecting on the reversibility degree of the enzyme after heating. Fig. 6 illustrates the relationship between the concentration of enzyme at heating and the degree of reactivation on the subsequent incubation, indicating that there is an optimum concentration for amylase to be reversibly inactivated by heat. The best

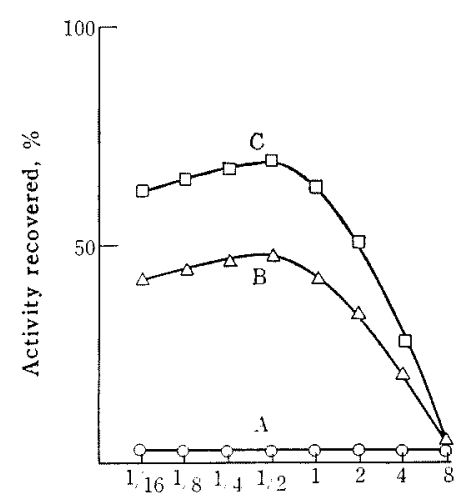

Conc. of amylase, $\mathrm{mg} / \mathrm{ml}$ (in log. scale)

FIG. 6. Concentration of Amylase and the Degree of Reactivation.

Solutions of $\mathrm{M} / 200$ borate buffer, $\mathrm{pH} 8.4$, containing vari ous amounts of amylase were heated at $85^{\circ} \mathrm{C}$ for $10 \mathrm{~min}$. and subsequently incubated at $30^{\circ}$ for the period indicated.

$A$, activity immediately after heating;

B. activity after $30 \mathrm{~min}$. on the subsequent incubation;

C, activity after $150 \mathrm{~min}$. on the subsequent incubation. 
reversibility was found with a solution of around $0.5 \mathrm{mg}$ amylase per $\mathrm{ml}$ and, at concentrations more than $8 \mathrm{mg}$ per $\mathrm{ml}$, no reversibility was observed.

5) Effect of addition of urea or alcohol. The effect of addition of urea or alcohol at heating on the reversible inactivation of amylase was investigated. A mixture solution of amylase

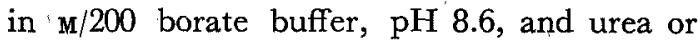
alcohol ( $3 \mathrm{~m}$ or $12.5 \%$ in the final conc., respectively) was heated at $85^{\circ} \mathrm{C}$ for $10 \mathrm{~min}$. and the enzyme activity was assayed at varied times during the subsequent incubation at $30^{\circ} \mathrm{C}$. However, the presence of urea or alcohol at heating resulted in the complete inactivation of enzyme and no reactivation was observed on the subsequent incubation.

\section{B. Factors affecting on the reactivation of the} heat-inactivated amylase

The reactivation of heat-inactivated amylase was found to be affected by several factors. Unless otherwise indicated, the amylase used in the experiment was the one that was inactivated by heating at $85^{\circ} \mathrm{C}$ for $10 \mathrm{~min}$. in $\mathrm{m} / 400$ borate buffer at $\mathrm{pH} 8.6$.

1) Temperature on incubating the heat-inactivated amylase. The heat-inactivated amylase was incubated at various temperatures and the recovery of enzyme activity was periodically investigated. In Fig. 7 are shown the results, indicating that there is an optimum

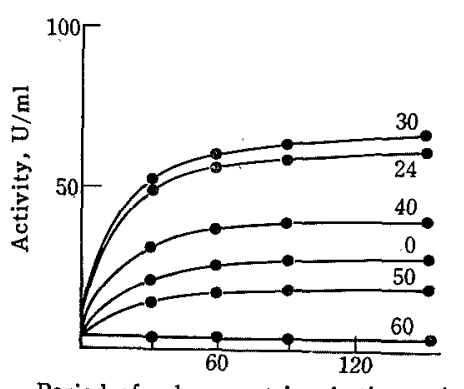

FIG. 7. Effect of Temperature on Reactivation of the Heat-Inactivated Amylase.

The numbers indicate the temperature ${ }^{\circ} \mathrm{C}$, at which the enzyme was incubated after heating. in the temperature for reactivation and the best reactivation occurs at $30^{\circ} \mathrm{C}$.

2) $\mathrm{pH}$ of incubation for reactivation. To the amylase heated in a borate buffer solution (M/400, pH 8.6) was added acetate buffer in about $\mathrm{M} / 60$ immediately after heating and the $\mathrm{pH}$ was adjusted to 5.8. The amylase heated in an acetate buffer solution ( $(\mathrm{M} / 400, \mathrm{pH} 5.8)$ was, on the other hand, added with $\mathrm{m} / 60$ borate buffer in the final concentration to adjust the $\mathrm{pH}$ to 8.6 and the change of enzyme activity was investigated. As shown in Fig. 8 , the inactivated amylase the $\mathrm{pH}$ of which was altered from acid to alkaline side caused reactivation (curve 4); while the enzyme treated in the reverse showed no reactivation (curve 2). This result indicates that the presence of $\mathbf{m} / 60$ acetate interferes the process of reactivation of the amylase reversibly inactivated by heat.

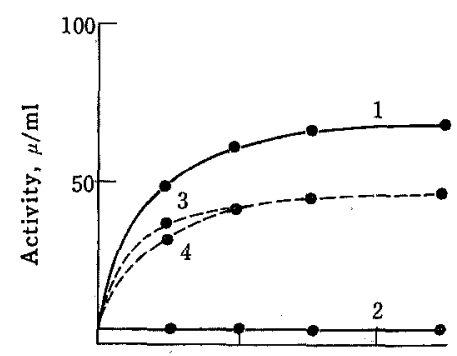

FIG. 8. Effect of $\mathrm{pH}$ on Reactivation of the Heat; Inactivated Amylase.

\begin{tabular}{ccc} 
Curve & \multicolumn{2}{c}{$\mathrm{pH}$} \\
1 & at heating & at subsequent incubation \\
2 & 8.6 & 8.6 \\
3 & 8.6 & 5.8 \\
4 & 5.8 & 5.8 \\
& 5.8 & 8.6
\end{tabular}

3) Effect of urea and ethanol. Urea or etha: nol was added to the amylase immediately after heating at $85^{\circ} \mathrm{C}$ for $10 \mathrm{~min}$. and the mixture was allowed to stand at $30^{\circ} \mathrm{G}_{\xi}$ but there was observed no reactivation of amylase, In this experiment, a solution' of $6 \mathrm{M}$ urea of $25 \%$ ethanol previously cooled at $0^{\circ} \mathrm{C}$ was added in a equal volume to the amylase right 
TABle I. Reactivation of AMYlase Inactivated By Heat AND SUBSEQUENTLY MIXED WITH UREA (3 M)

\author{
Treatment \\ Before heating \\ Right after heating \\ After incubating the heated \\ enzyme at $25^{\circ} \mathrm{C}, 2 \mathrm{hr}$.
}

Activity
1000

620
(After dilution and incubation

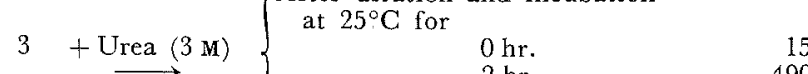

Treatment

$2 \mathrm{hr}$.

Activity 5

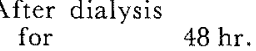

after heating. However, dialysis of the mixture against deionized water caused an appreciable recovery of enzyme activity, as is seen in Table I. Dilution of the mixture with water to decrease the concentration of the additions resulted in a similar effect of reactivation. By diluting with water, a similar result but with less degree of reactivation was observed with the enzyme mixed with ethanol after heating.

In Table II is presented the effect of various concentrations of urea on the heat-incativated amylase, showing that the addition of urea in $3 \mathrm{M}$ in the final concentration to the heated amylase completely inhibits reactivation of the enzyme, while, in the case of the addition of $1 \mathrm{~m}$ urea, the heated enzyme is spontaneously reactivated to a similar degree to that found with the amylase without any addition of urea. The activity of native amylase was not affected by $3 \mathrm{M}$ urea on incubation over 20 hours at $25^{\circ} \mathrm{C}$. It is followed that these facts make it possible to

\section{TABle II. EFFECT OF VARIED CoNCENTRATIONS OF UREA ON REACTIVATION OF THE HEAT- INACTIVATED AMYLASE}

\begin{tabular}{|c|c|c|c|}
\hline \multirow{3}{*}{$\begin{array}{c}\text { Conc. } \\
\text { of urea, } \\
\text { M }\end{array}$} & \multicolumn{3}{|c|}{ Activity } \\
\hline & Immediately & After the & nt incuba \\
\hline & aiter liteding & $3 \mathrm{hr}$. & 20 hr. \\
\hline 0 & 5 & 600 & 600 \\
\hline 1 & 一 & $595(600)$ & $600(600)$ \\
\hline 2 & - & $310(590)$ & $310(600)$ \\
\hline 3 & - & $5(470)$ & $5(230)$ \\
\hline 4 & 一 & $5(410)$ & $5(95)$ \\
\hline
\end{tabular}

* Incubated at $25^{\circ} \mathrm{C}$. The number in parenthesis indicates the enzyme activity determined after diluting the mixture to $1 \mathrm{M}$ of urea. preserve the heated amylase in a reversibly inactivated state, since the reactivation of amylase inactivated by heat is reversibly prevented by the presence of 2 to $3 \mathrm{M}$ urea and the preventive effect of urea is removed by only diluting with water decreasing the concentration of urea in less than $1 \mathrm{~m}$. However, the degree of reversibility of the amylase inactivated by heat and subsequently mixed with $3 \mathrm{M}$ urea was less than that of amylase

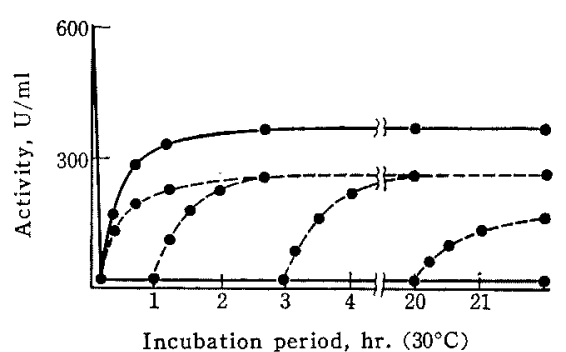

FIG. 9. Effect of Incubation Period on Reactivation of the Amylase Inactivated by Heating and Subsequently Mixed with $3 \mathrm{M}$ Urea.

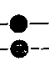

, without urea;

with urea; the curves show that the amylase is reactivated in 1 to $2 \mathrm{hrs}$ after diluting the amylaseureas mixture.

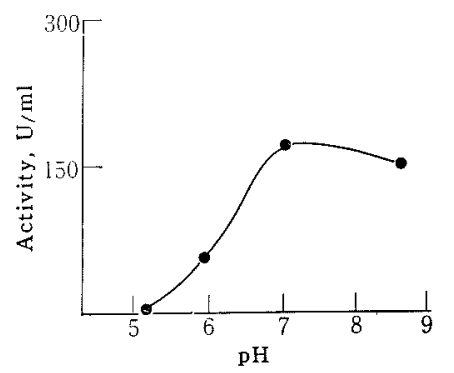

FIG. 10. Effect of $\mathrm{pH}$ on Reactivation of the Amylase Inactivated by Heat and Mixed with Urea. 
without urea, and the longer the period of incubation with $3 \mathrm{~m}$ urea, the less reactivation of amylase was observed (Fig. 9). The reactivation of amylase inactivated by heat and mixed with urea was also influenced by $\mathrm{pH}$. To the heat-inactivated amylase being incubated with $3 \mathrm{M}$ urea at $30^{\circ} \mathrm{C}$ for $150 \mathrm{~min}$. was added a twice-volume portion of veronal buffer (im/60) of various $\mathrm{pH}$ values and the activity recovery was investigated. As shown in Fig. 10 , the reactivation occurred at $\mathrm{pH}$ values between 7 and 8.8 .

4) Effect of the addition or removal of calcium. The effect of calcium ions on amylase at heating was already found to result in irreversible inactivation of enzyme. Also, it has been found that the amylase reversibly inactivated by removal of calcium with EDTA is sensitive to heat." In this section, the effect of addition or removal of calcium on the amylase inactivated by heat was investigated. To the amylase $(1 \mathrm{mg} / \mathrm{ml})$ immediately after heating at $85^{\circ} \mathrm{C}$ for $10 \mathrm{~min}$. in a dilute sodium hydroxide solution $(\mathrm{pH} 8.6)$ was added a cold solution of calcium acetate or ethylenediaminetetraacetic acid ammonium salt (EDTA) with or without urea. After certain period of incubation at $25^{\circ} \mathrm{C}$, the mixture was diluted with water and again incubated for further 3 hours. The enzyme activity was then assayed on a soluble starch solution with or without $\mathrm{Ca}^{++}$. As given in Table III, only the heat-inctivated amylase which was incubated without calcium salt or EDT.A showed reactivation. In comparison, a similar experi ment was carried out with native amylase and the enzyme mixed with EDTA in the presence of urea was irreversibly. inactivated with sharp contrast to the amylase incubated with only EDTA; the latter enzyme showed quite the same activity as the original when assayed on a starch solution containing calcium ions.

\section{Some Properties of the Amylase Reversibly} Inactivated by Heat

The properties of the heat-inactivated amylase may be seen in part from the investigation on the factors affecting on reactivation of the inactivated amylase which have been described above. In this section were investigated some other properties of the heat-inactivated amylase.

1) Spectroscopical properties of the amylase. On heating amylase at $85^{\circ} \mathrm{C}$ for $10 \mathrm{~min} .$, a blue shift was clearly observed in the absorption spectra of the enzyme. Fig. 11 illustates the difference spectra which were measured at given wavelengths as a function of incubation period at $30^{\circ} \mathrm{C}$ after heating, showing that the difference in the spectra appears most remarkably at regions of $292 \sim 293$ and $283 \sim 285 \mathrm{~m} \mu$. The result also indicates that the value of difference in the absorption spectra gradually decreases approximately in-

TABLE III. EFFECT OF ADDITION OF CALCIUM IONS OR EDTA ON THE HEAT-INACTIVATED AMYLASE

\section{Amylase}

Heat-inactivated

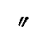

"

r

Native

"

"
Treatment

(diluent, $\mathrm{pH}$, incubation period at $25^{\circ} \mathrm{C}$ )

$\mathrm{H}_{2} \mathrm{O}, \mathrm{pH} 7.4,3 \mathrm{hr}$.

Ca-acetate $(\mathrm{M} / 200), \mathrm{pH} 7.6,4 \mathrm{hr}$.

EDTA (M/300), pH 7.6, $4 \mathrm{hr}$.

EDTA $(\mathrm{M} / 300)$ + urea $(3 \mathrm{M}), \mathrm{pH} 7.6,4 \mathrm{hr}$.

$\mathrm{H}_{2} \mathrm{O}, \mathrm{pH} 6.0,3 \mathrm{hr}$.

$\operatorname{EDTA}(\mathbf{M} / 300), \mathrm{pH} 6.0,24 \mathrm{hr}$.

EDTA $(\mathbf{M} / 300)+$ urea $(3 \mathrm{M})$, pH 6.0, $6 \mathrm{hr}$.
Activity recovered, $\%$ on starch

$\begin{array}{cc}\text { without } \mathrm{Ca}^{++*} & \text { with } \mathrm{Ca}++* * \\ 38 & 60 \\ 0 & 0 \\ 0 & 0 \\ 0 & 0 \\ 75 & 100 \\ 0 & 100 \\ 0 & 0\end{array}$

* The soluble starch used for activity assay was dissolved in M/500 EDTA-( NH 4$)_{3}$ and buffered with M/50 acetic acid-ammonium acetate at pH 5.9 .

** To the soluble starch used as the standard was added $\mathrm{M} / 500 \mathrm{Ca}$-acetate. 


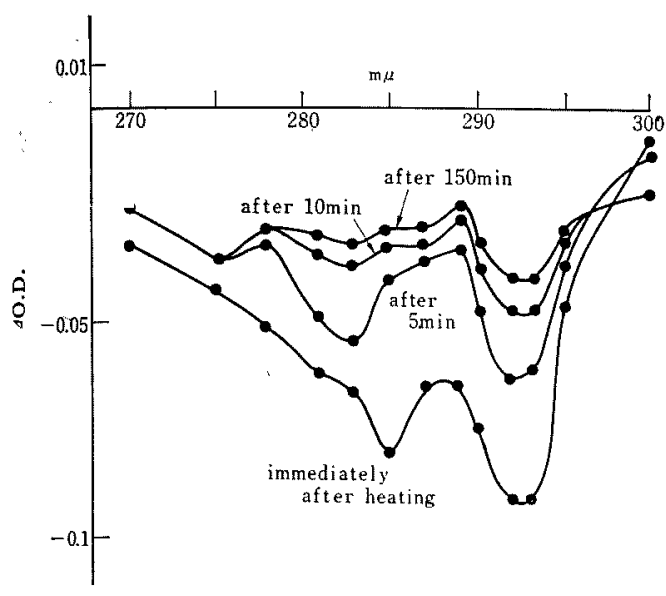

FIG. 11. Difference Absorption Spectra of Bac. subtilis' $\alpha$-Amylase Reversibly Inactivated by Heat.

A solution of amylase $(0.47 \mathrm{mg}$ amylase $/ \mathrm{ml}$ of $\mathrm{M} / 400$ borate buffer $\mathrm{pH} 8.6, E^{280 \mathrm{~m} t}=1.18$ ) was heated at $85^{\circ} \mathrm{C}$ for $10 \mathrm{~min}$. and, immediately after cooling at $25^{\circ} \mathrm{C}$, its absorb. ancy was determined against the unheated amylase solution at a given wavelength as a function of time.

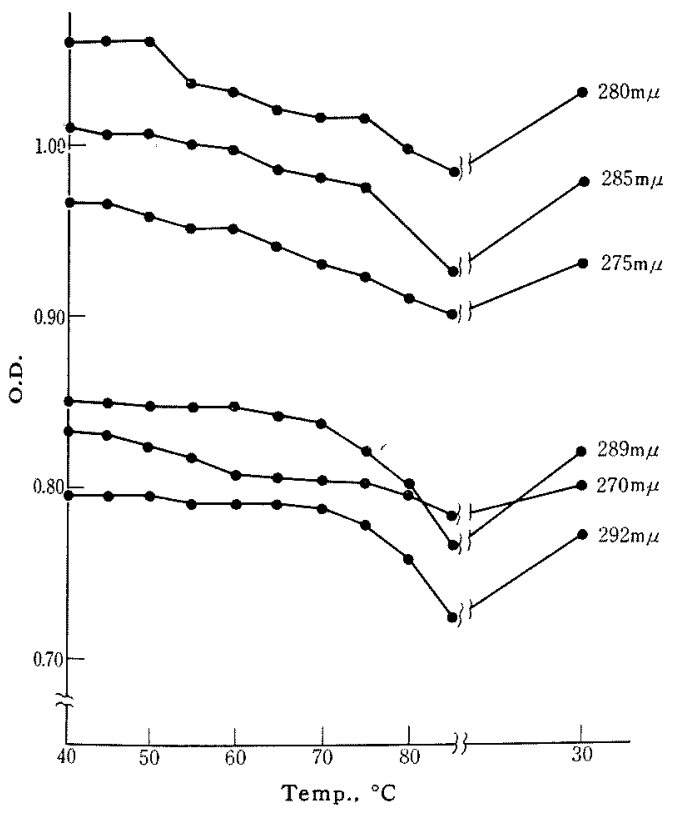

FIG. 12. Changes with Temperature of Absorption of Bac. subtilis' $\alpha$-Amylase at Various Wave Lengths.

Amylase; $0.424 \mathrm{mg}$ per $\mathrm{ml}$ of $\mathrm{M} / 400$ borate buffer, $\mathrm{pH} 8.6$. The temperature was raised at a rate of approximately $5^{\circ} \mathrm{C}$ in every $2 \mathrm{~min}$., up to $65^{\circ} \mathrm{C}$, but at temperatures higher than this, the rate was gradually decreased and 5 min. was teken between $80^{\circ} \mathrm{C}$ and $85^{\circ} \mathrm{C}$. versely with reactivation of amylase.

The change in absorption spectra was also investigated as a function of temperature. As shown in Fig. 12, the decrease in the absorption already began at $50^{\circ}$ to $60^{\circ} \mathrm{C}$ and, the higher the temperature, the more decrease was observed. In the experiment, the absorption spectra were measured against water as the control, raising the temperature of the thermostat for cuvette by the aid of Haake's water-circulating thermostat. Since the rate of rising in temperature could not be uniformly regulated and a longer time was required to get $85^{\circ} \mathrm{C}$, the result obtained there seems not to be comparable with those in Fig. 11, but the reversibility of change in the absorption spectra is observed.

2) Susceptibility of the heat-inactivated amylase to proteolytic enzyme. The amylase reversibly inactivated by heat was extremely sensitive to proteolytic enzyme. A solution of amylase $(0.5 \mathrm{mg} / \mathrm{ml}$ of $\mathrm{m} / 240$ borate buffer, $\mathrm{pH}$ 8.6) was heated at $85^{\circ} \mathrm{C}$ for $10 \mathrm{~min}$. and then incubated at $30^{\circ} \mathrm{C}$. At varied times of incubation, a $3 \mathrm{ml}$ aliquote was taken into $0.5 \mathrm{ml}$ of Bac. subtilis' alkaline protease (Nagarse, $0.06 \mathrm{mg}$ ) and the mixture was again incubated at $30^{\circ} \mathrm{C}$, assaying the amylase activity. As shown in Fig. 13, the amylase

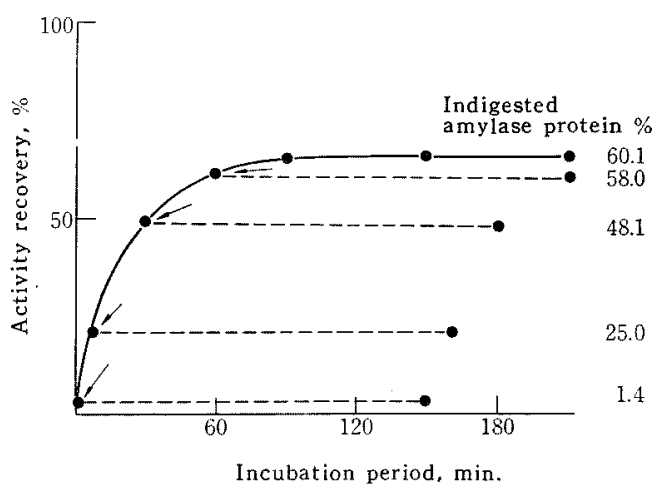

FIG. 13. Effect of Protease on the Heat-Inactivated Amylase.

The heated amylase on the subsequent incubation was mixed with protease at the time indicated by arrows. 
exposed to the protease right after heat-treatment showed no activity even on a long incubation. On the other hand, the amylase restoring activity on the subsequent incubation was stopped to recover more activity by the addition of protease. A test of the fractional determination of native and denatured amylase revealed that the amylase activity remaining in the incubation mixture with protease was just comparable to the amount of indigestive amylase protein.

\section{DISCUSSION}

The present works demonstrated the heatinactivated Bac. subtilis' $\alpha$-amylase to be reactivated to a great extent under a certain condition. From the experiment on the absorption spectra of the enzyme and the behavior toward proteinase, it is evident that the reversibility of inactivation of the enzyme by heat and reactivation on the subsequent incubation are achieved, accompanying a certain marked change in conformation of the enzyme protein.
It is of interest that the reversibility of heat-inactivation of the enzyme occurs easily at alkaline sides. The result shown in Fig. 8 indicated the reactivation of the inactivated amylase to be prevented by the presence of a certain concentration of buffer at acid sides. A similar phenomenon has been known with Taka-amylase $^{11)}$ and several other amylases which will be reported elsewhere.

It is also interesting that the addition of calcium ions either before and after heating significantly inhibits the reversibility of the enzyme, in spite of a marked stabilization effect for the native amylase under various conditions. Generally, the reversible inactivation of the enzyme was not obtained where some precipitates occurred on heating the enzyme solution, and the addition of calcium salts, even to the amylase right after heating, always resulted in formation of precipitate under the condition described above. The added calcium may affect the enzyme protein so as for the conformation not to transform reversibly. However, the calcium originally

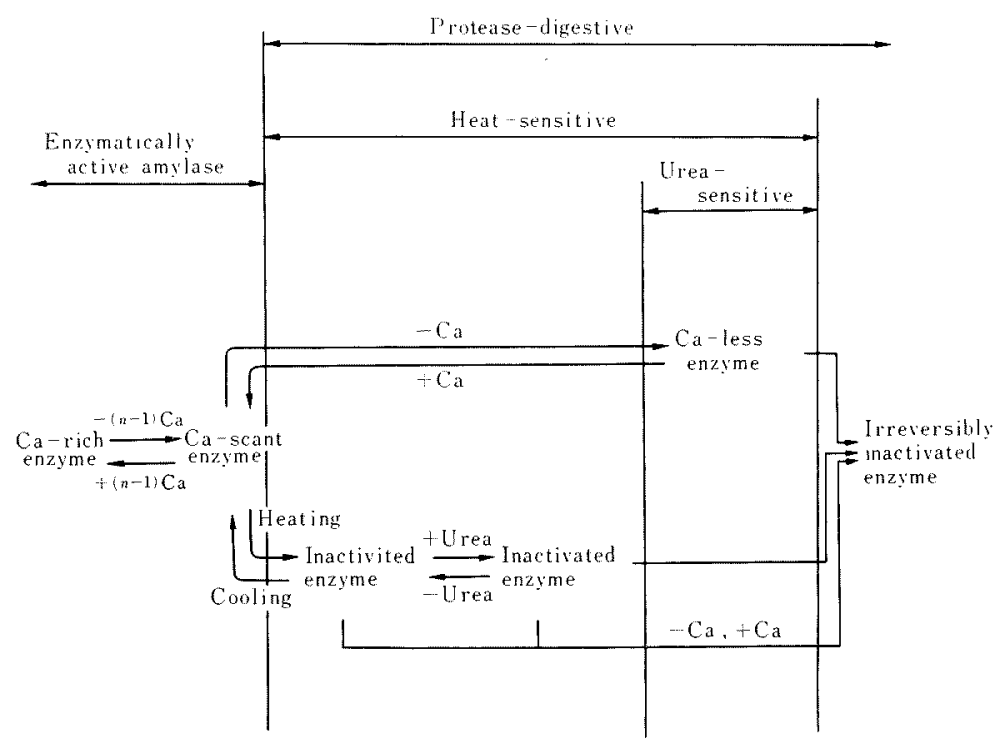

FIG. 14. A Diagram Showing the Process of Reversible Inactivation of Bac. subtilis' $\alpha$-Amylase.

11) A. Tanaka, This Jouanal, 24, 152 (1960). 
contained in the enzyme preparation seems to play an important role in the reversibility, because the amylase freed from calcium is extremely sensitive to heat and, on the other hand, the addition of EDTA to the heat-inactivated amylase leads to irreversible inactivation of the enzyme.

The fact that the addition of urea to the heat-inactivated amylase inhibits reactivation of the enzyme and removal of the urea makes to cause reactivation, seems important in the investigation of the reversible inactivation of enzyme. Early in 1936, Anson had found reversibility of heat-inactivation of trypsin." His findings might have been favored by use of hemoglobin as the substrate which contained urea in order to denature the substrate. By applying this effect of urea it was found ${ }^{12)}$ that the heat-inactivated amylase showed no reactivity with the antisera to native $B a c$. subtilis' $\alpha$-amylase and, as the inactivated amylase was reactivated, the reactivity with the antisera was also recovered, the details of which experiments will be published elsewhere.

From the facts in the present work together with those ever reported by several workers, the nature of Bac. subtilis' $\alpha$-amylase in special reference to the stability may be summarized as shown in Fig. 14.

12) T. Maruyama, M. Niwa, T. Yamamoto, A. Nishida and J. Fukumoto, I. Biochem., Tokyo, 60, 286 (1969). 